\title{
PENGARUH ASIMETRI INFORMASI DAN MANAJEMEN LABATERHADAP BIAYA MODAL EKUITAS PADA PERUSAHAAN MANUFAKTUR YANG TERDAFTAR DI BURSA EFEK INDONESIA (BEI) TAHUN 2013-2015
}

\author{
Yudi Partama Putra \\ Universitas Muhammadiyah Bengkulu \\ akoeyudi94@yahoo.com
}

\begin{abstract}
ABSTRAK
Yudi Partama Putra; Penelitian ini bertujuan untuk (1) mengetahui pengaruh asimetri informasi mengenai biaya ekuitas pada perusahaan manufaktur yang terdaftar di Bursa Efek Indonesia periode 2013-2015, (2) mengetahui pengaruh manajemen laba terhadap biaya modal saham pada perusahaan manufaktur yang terdaftar di Bursa Bursa Efek pada tahun 2013- 2015, (3) menentukan pengaruh asimetris informasi dan manajemen laba secara simultan terhadap biaya modal ekuitas pada perusahaan manufaktur yang terdaftar di Bursa Efek Indonesia 2013-2015.

Populasi dalam penelitian ini adalah perusahaan manufaktur yang terdaftar di Bursa Efek Indonesia. Sedangkan pemilihan sampel diambil dengan menggunakan metode purposive sampling. Uji asumsi klasik yang digunakan dalam penelitian ini adalah uji normalitas, uji multikolinieritas, uji heteroskedastisitas, dan uji autokorelasi. Analisis data yang digunakan untuk menguji hipotesis adalah teknik analisis regresi linier berganda.

Berdasarkan hasil penelitian menunjukkan bahwa (1) asimetri informasi berpengaruh positif dan signifikan terhadap biaya ekuitas (2) manajemen laba tidak berpengaruh signifikan terhadap biaya ekuitas. Hasil uji F menunjukkan bahwa variabel asimetri informasi dan manajemen laba secara simultan mempengaruhi biaya modal ekuitas. Hasil uji koefisien determinasi dengan $\mathrm{R}$ square menunjukkan bahwa variabel asimetri informasi dan earnings management mempengaruhi cost equity capital sebesar $10,7 \%$, sedangkan sisanya $89,3 \%$ dipengaruhi oleh variabel lain.
\end{abstract}

\section{ABSTRACT}

Yudi Partama Putra; This study aims to (1) determine the effect of asymmetry of information on costs of equity at manufacturing companies listed in Indonesia Stock Exchange period 2013-2015, (2) know the effect of earnings management on equity capital costs at manufacturing companies listed on the Stock Exchange in 2013-2015, (3) determine the effect of information asymmetry and earnings management simultaneously on the cost of equity capital in manufacturing companies listed on the Indonesian Stock Exchange 2013-2015.

The population in this study is manufacturing company listed on the Indonesia Stock Exchange. While the sample selection is taken by using purposive sampling method. The classical assumption test used in this research is using normality test, multicollinearity test, heteroscedasticity test, and autocorrelation test. Analysis of data used to test the hypothesis is multiple linear regression analysis techniques.

Based on the results of the research indicate that (1) information asymmetry has positive and significant effect to cost of equity (2) earnings management has no significant effect on Cost of equity. F test results show that the variable information asymmetry and earnings management simultaneously affect the cost of equity capital. The result of determination coefficient test with $R$ square shows that variable information asymmetry and earnings management influence cost equity capital equal 10,7\%, while the rest $89,3 \%$ influenced by other variables.

Key Words: Information Asymetry, Earnings Management, and Cost Of Equity.

\section{LATAR BELAKANG}

Pengguna laporan keuangan seringkali hanya fokus kepada informasi laba, tanpa memperhatikan bagaimana laba tersebut dihasilkan. Hal ini mendorong manajemen perusahaan untuk melakukan beberapa tindakan yang disebut manajemen laba atau manipulasi laba (earnings management). Menurut Setiawati dan Saputro (2004) dalam Ifonie (2012:104) menyatakan bahwa manajemen laba adalah campur tangan manajemen dalam proses penyusunan laporan keuangan eksternal guna mencapai tingkat laba tertentu dengan tujuan untuk menguntungkan dirinya sendiri (atau perusahaannya sendiri). 
Para akademis, termasuk peneliti berargumen bahwa manajemen laba pada dasarnya merupakan dampak dari kebebasan seorang manajer untuk memilih dan menggunakan metode akuntansi tertentu ketika mencatat dan menyusun informasi dalam laporan keuangan. Meski metode dan prosedur akuntansi yang dipilih dan digunakan masih dalam ruang lingkup prinsip akuntansi, maka apa yang dilakukan manajer dikategorikan sebagai kecurangan. Oleh sebab itu upaya untuk mengurangi manajemen laba dianggap sebagai upaya untuk melakukan koreksi terhadap standar akuntansi (Sulistyanto, 2014:4)

Dalam kaitannya dengan biaya modal ekuitas, tujuan dari manajemen laba adalah untuk memaksimumkan atau meminimumkan laba sehingga dapat berpengaruh terhadap tinggi rendahnya dividen yang akan diterima investor. Jika manajemen laba bertujuan untuk memaksimumkan laba, maka dividen perusahaan akan tinggi. Demikian juga sebaliknya, jika manajemen laba bertujuan untuk meminimumkan laba, maka dividen perusahaan akan rendah. Selain itu apabila perusahaan memiliki laba yang rendah, ada kemungkinan perusahaan tidak membagikan dividen. Biaya modal ekuitas bagi perusahaan merupakan biaya riil yang harus dikeluarkan dalam mendapatkan dana dari sisi ekuitas, sehingga kecenderungannya biaya modal tersebut harus diminimalisir. Dalam upaya meminimalisir biaya yang rendah untuk modal ekuitas, maka perusahaan menerbitkan suatu pengungkapan yang dapat menurunkan ekspektasi investor terhadap risiko dan mengurangi asimetri informasi dimana masingmasing menunjukkan pengurangan biaya modal.

Informasi yang digunakan investor untuk mengambil keputusan tidak lepas dari ukuran perusahaan, karena ukuran perusahaan merupakan ukuran ketersediaan informasi. Semakin besar perusahaan berarti semakin besar informasi yang harus diungkapkan oleh perusahaan yang berkonsekuensi menimbulkan biaya untuk menyediakan informasi atau biaya modal ekuitas. Kepercayaan investor didasari atas berbagai informasi yang diterima mengenai kodisi perusahaan, jika informasi yang diterima tidak sesuai dengan kenyataan maka akan berpotensi menimbulkan konflik keagenan. Asymetriy Information atau ketidaksamaan informasi adalah situasi dimana manajer lebih mengetahui informasi internal dan prospek perusahaan di masa yang akan datang dibandingkan dengan pemegang saham dan stakeholder lainnya. Aktivitas yang dilakukan investor di pasar modal ditentukan oleh informasi yang mereka peroleh baik secara langsung (laporan publik) maupun tidak langsung (insider trading). Beberapa penelitian mengenai manajemen laba dan asimetri informasi terhadap biaya ekuitas memberikan hasil yang berbeda. Utami (2005), membuktikan bahwa manajemen laba mempunyai pengaruh positif dan signifikan terhadap biaya modal ekuitas, artinya bahwa semakin tinggi tingkat akrual, maka semakin tinggi biaya modal ekuitas dan perusahaan cenderung melakukan income increasing accruals. Sedangkan penelitian Ifonie (2012) menghasilkan tidak ada pengaruh yang signifikan antara asimetri informasi dan manajemen laba terhadap biaya modal ekuitas dimana investor tidak hanya melihat hasil laporan keuangan tetapi melihat faktor lain dalam mengambil keputusan untuk menanamkan uang dalam perusahaan. Penelitian Jumirin (2012), menemukan bahwa manajemen laba berpengaruh signifikan terhadap biaya modal ekuitas pada perusahaan Manufaktur. Pada penelitian Perwira (2015) menghasilkan bahwa asimetri inforamsi tidak berpengaruh signifikan terhadap biaya modal ekuitas, hal ini menunjukkan bahwa besar kecilnya asimetri informasi tidak mampu meningkatkan biaya modal ekuitasnya dan variebel manajemen laba juga tidak berpengaruh signifikan terhadap biaya modal ekuitas yang menunjukan bahwa besar kecilnya perilaku manajemen laba tidak menentukan peningkatan niaya modal ekuitas.

Adanya perbedaan hasil penelitian tersebut, maka penting untuk dilakukan melakukan penelitian lanjutan mengenai biaya modal ekuitas dan faktor-faktor yang mempengaruhinya. Hal ini dimaksudkan untuk memperoleh informasi hasil penelitian yang berbeda dan lebih baik. Penelitian yang akan dilakukan menggunakan objek perusahaan manufaktur. Penggunaan perusahaan manufaktur dikarenakan perusahaan pada sektor ini paling banyak mendapatkan perhatian dari para investor, selain itu perusahaan manufaktur juga memiliki masa depan yang baik sehingga menjanjikan pengembalian saham yang lebih tinggi dan memberikan keuntungan bagi investor. Adapun perbedaan penelitian ini dari penelitian terdahulu yaitu dimana periode pengamatan menjadi 3 (tiga) tahun (2013-2015) dan proksi manajemen laba menggunakan akrual modal kerja dengan penjualan tidak sama halnya dengan penelitian Ifonie (2012) yang menggunakan The Modified Jones Model.. Akan tetapi penelitian ini terdapat kesamaan dengan penelitian sebelumnya yaitu biaya modal ekuitas menggunakan model Ohlson (1995) dalam Ifonie (2012) dan proksi asimetri informasi menggunakan model yang dipakai Komalasari (2000) dalam Ifonie (2012) yaitu menghitung bid-ask spread dengan jenis Market Spread. 


\section{LANDASAN TEORI}

Biaya Modal Ekuitas

Biaya modal ekuitas merupakan sebuah perhitungan tingkat diskonto yang dikenakan pada saham perusahaan oleh pelaku pasar atas dasar perkiraan arus kas masa depan perusahaan untuk menentukan harga saham saat ini (Mangena et. al., 2010 dalam Pratista 2013). Menurut Utami (2005), biaya modal merupakan konsep yang dinamis yang dipengaruhi oleh beberapa faktor ekonomi. Struktur biaya modal didasarkan pada beberapa asumsi yang berkaitan dengan resiko dan pajak. Asumsi dasar yang digunakan dalam estimasi biaya modal adalah resiko bisnis dan resiko keuangan adalah tetap (relatif stabil).

Variabel dependen dalam penelitian ini adalah cost of equity capital perusahaan. Cost of equity capital adalah biaya yang dikeluarkan untuk membiayai sumber pendanaan (source finance). Perhitungan cost of equity capital setiap perusahaan sampel dengan menggunakan model residual income yang lebih dikenal dengan Edward Bell Ohlson valuation (Utami, 2005) yaitu:

$$
r=(B t+X t+1-P t) / P t
$$

Keterangan :

$\mathrm{r} \quad$ = biaya modal ekuitas

$\mathrm{B}_{\mathrm{t}} \quad=$ nilai buku per lembar saham periode $\mathrm{t}$

$\mathrm{X}_{\mathrm{t}+1} \quad$ = laba per lembar saham pada periode $\mathrm{t}+1$

$\mathrm{P}_{\mathrm{t}} \quad=$ harga saham pada periode $\mathrm{t}$

\section{Asimetri Informasi dan Manajemen Laba}

Variabel independen dalam penelitian ini adalah asimetri informasi dan manajemen laba. Asimetri informasi merupakan ketimpangan informasi antara manajer dengan pemegang saham, di mana manajer lebih mengetahui informasi internal dan prospek perusahaan di masa yang akan datang dibandingkan pemegang saham atau stakeholder lainnya. Asimetri informasi dalam penelitian ini diukur menggunakan model teori bid-ask spread (Komalasari, 2000) dalam (Ifonie, 2012).

$$
\text { SPREAD }_{i, t}=\left[\left(\text { ask }_{\mathrm{i}, \mathrm{t}}-\text { bid }_{\mathrm{i}, \mathrm{t}}\right) /\left\{\left(\text { ask }_{\mathrm{i}, \mathrm{t}}+\text { bid }_{\mathrm{i}, \mathrm{t}}\right) / 2\right\}\right] \times 100
$$

Keterangan:

Ask $_{\mathrm{i}, \mathrm{t}}$ : harga ask tertinggi saham perusahaan i yang terjadi pada hari t (pada tanggal publikasi annual report)

Bid $_{\mathrm{i}, \mathrm{t}} \quad$ : harga bid terendah saham perusahaan i yang terjadi pada hari t (pada tanggal publikasi annual report)

Manajemen laba diproksi dengan menggunakan model Utami (2005) yang mengukur berdasarkan rasio akrual modal kerja dengan penjualan. Rumus yang digunakan dalam penelitian ini adalah:

\section{Manajemen Laba = Akrual Modal Kerja (t) / Penjualan periode (t)}

$$
\text { Akrual Modal Kerja }=\Delta \mathrm{AL}-\Delta \mathrm{HL}-\Delta \mathrm{kas}
$$

Keterangan:

$\Delta \mathrm{AL}=$ Perubahan aktiva lancar pada periode $\mathrm{t}$

$\Delta \mathrm{HL}=$ Perubahan hutang lancar pada periode $\mathrm{t}$

$\Delta$ Kas $=$ Perubahan kas dan ekuitas kas pada periode $t$

Dalam penelitian ini data akrual modal kerja dapat diperoleh langsung dari laporan arus kas aktivitas operasi, yang digunakan dalam penelitian Utami (2005), sehingga investor dapat langsung memperoleh data tersebut tanpa melakukan perhitungan yang rumit.

\section{PENGEMBANGAN HIPOTESIS}

Asimetri informasi adalah ketidakseimbangan informasi antara manajer dan pemegang saham atau pemangku kepentingan lainnya, di mana para manajer mengetahui informasi internal dan prospek perusahaan di masa depan daripada pemegang saham. Ketika informasi simetri meningkat, 
pengungkapan keputusan yang dibuat oleh manajer dapat mempengaruhi harga saham karena adanya informasi asimetris antara investor yang lebih banyak informasi dan investor yang kurang mendapat informasi meningkatkan biaya transaksi dan mengurangi likuiditas yang diharapkan di pasar untuk saham perusahaan. Penelitian tentang pengaruh asimetri informasi terhadap biaya modal ekuitas sebelumnya telah dilakukan oleh beberapa peneliti. Penelitian Heriyanthi (2013), Dewi dan Chandra (2016) dan Nuryaman (2014) yang menyimpulkan bahwa asimetri informasi mempengaruhi biaya modal ekuitas.

Hal ini menunjukkan semakin tinggi asimetri informasi suatu perusahaan, semakin riskan saham perusahaan sehingga investor akan berpikir dua kali untuk berinvestasi dan investor akan mengharapkan return yang lebih besar. Biaya modal ekuitas digunakan untuk menentukan tingkat pengembalian investasi. Bila investasi meningkat, biaya modal ekuitas akan menurun. Dampak adanya asimetri informasi juga bisa dilihat pada volume perdagangan saham dan spread terjadi. Ketika asimetri informasi meningkat, hal itu dapat menyebabkan volume perdagangan kecil karena investor meragukan keakuratan laporan keuangan mereka yang mempengaruhi tingkat pengembalian yang diharapkan oleh investor.

H1: Asimetri informasi berpengaruh terhadap manajemen laba

Manajemen laba menyebabkan banyak informasi yang harus diungkapkan oleh perusahaan, sehingga konsekuensi kenaikan biaya yang dikeluarkan perusahaan untuk memberikan informasi kepada publik (cost of equity capital), dimana biaya modal ekuitas adalah return yang diminta oleh penyedia dana, baik investor maupun kreditor. Semakin besar indikasi manajemen laba berarti semakin besar biaya modal ekuitas. Penelitian Jumirin (2011) mengungkapkan bahwa manajemen laba memiliki pengaruh yang signifikan terhadap biaya modal ekuitas, begitu juga penelitian yang dilakukan oleh Utami (2005), Dewi dan Chandra (2016) dan Pratista (2012). Hal ini menunjukkan bahwa investor sudah mengantisipasi secara benar informasi yang berkaitan dengan manajemen laba mereka. Semakin tinggi manajemen laba oleh manajemen, semakin tinggi pula biaya modal ekuitas. Namun hasil penelitian lain yaitu Ifonie (2012), menyimpulkan bahwa manajemen laba tidak mempengaruhi biaya modal ekuitas. Berdasarkan uraian di atas, hipotesis dalam penelitian ini adalah:

H2: Manajemen laba berpengaruh terhadap biaya modal ekuitas

\section{METODOLOGI}

Jenis penelitian ini adalah penelitian kuantitatif. Populasi dalam penelitian ini adalah seluruh perusahaan manufaktur yang berjumlah 143 perusahaan yang terdaftar di Bursa Efek Indonesia (BEI) tahun 2013 hingga 2015. Sampel dalam penelitian ini dipilih menggunakan metode purposive sampling yaitu pengambilan sampel yang berdasarkan kriteria tertentu, yaitu:

1. Perusahaan manufaktur yang terdaftar di Bursa Efek Indonesia selama periode 2013-2015.

2. Perusahaan manufaktur yang mempublikasikan laporan tahunan (annual report) yang lengkap untuk seluruh variabel selama periode 2013-2015.

3. Perusahaan mempunyai tahun buku yang berakhir 31 Desember dan nilai buku ekuitas positif untuk tahun 2013-2015.

4. Perusahaan yang menggunakan mata uang rupiah dalam laporan keuangan tahunannya selama periode tahun 2013-2015.

5. Perusahaan tidak delisting selama periode 2013-2015.

Berdasarkan kriteria yang telah ditetapkan maka jumlah sampel dalam penelitian ini adalah 28 perusahaan, dengan periode pengamatan sebanyak 3 tahun, sehingga diperoleh total pengamatan sebanyak 84 . Berikut sampel perusahaan dalam penelitian ini. 
Tabel 1. Sampel Perusahaan Manufaktur

\begin{tabular}{|c|c|l|}
\hline No & Kode & \multicolumn{1}{|c|}{ Nama Perusahaan } \\
\hline 1 & ADES & Akasha Wira International Tbk. \\
\hline 2 & AKPI & Argha Karya Prima Industry Tbk. \\
\hline 3 & ALMI & Alumindo Light Metal Industry Tbk. \\
\hline 4 & ALTO & Tri Banyan Tirta Tbk. \\
\hline 5 & AMFG & Asahimas Flat Glass Tbk. \\
\hline 6 & ASII & Astra International Tbk \\
\hline 7 & AUTO & Astra Otoparts Tbk. \\
\hline 8 & BAJA & Saranacentral Bajatama Tbk. \\
\hline 9 & BATA & Sepatu Bata Tbk. \\
\hline 10 & BTON & Betonjaya Manunggal Tbk. \\
\hline 11 & BUDI & Budi Starch \& Sweetener Tbk. \\
\hline 12 & CEKA & Wilmar Cahaya Indonesia Tbk. \\
\hline 13 & CPIN & Charoen Pokphand Indonesia Tbk \\
\hline 14 & DART & Duta Anggada Realty Tbk. \\
\hline 15 & DLTA & Delta Djakarta Tbk. \\
\hline 16 & DPNS & Duta Pertiwi Nusantara Tbk. \\
\hline 17 & DVLA & Darya-Varia Laboratoria Tbk. \\
\hline 18 & GDST & Gunawan Dianjaya Steel Tbk. \\
\hline 19 & GJTL & Gajah Tunggal Tbk. \\
\hline 20 & INAI & Indal Aluminium Industry Tbk. \\
\hline 21 & INDF & Indofood Sukses Makmur Tbk. \\
\hline 22 & JPRS & Jaya Pari Steel Tbk \\
\hline 23 & KBLM & Kabelindo Murni Tbk. \\
\hline 24 & KIAS & Keramika Indonesia Assosiasi Tbk. \\
\hline 25 & TOTO & Surya Toto Indonesia Tbk. \\
\hline 26 & ULTJ & Ultra Jaya Milk Industry \& Trading \\
\hline 27 & UNVR & Unilever Indonesia Tbk. \\
\hline 28 & WIIM & Wismilak Inti Makmur Tbk. \\
\hline & & \\
\hline & WWW.sa & \\
\hline 19 & & \\
\hline & &
\end{tabular}

Sumber : www.sahamok.com

Data yang digunakan dalam penelitian ini adalah data laporan keuangan tahunan perusahaan manufaktur yang terdaftar di Bursa Efek Indonesia (BEI) selama tahun 2013 dan tahun 2015. Adapun bentuk model yang akan diuji dalam penelitian ini, yaitu:

$$
\mathbf{r}=\mathbf{a}+\boldsymbol{\beta}_{1} \mathbf{X}_{1}+\boldsymbol{\beta}_{2} \mathbf{X}_{2}+\mathbf{e}
$$

$$
\begin{array}{ll}
\text { Keterangan: } \\
\mathrm{r} & =\text { Biaya modal ekuitas } \\
\mathrm{a} & =\text { Konstanta } \\
\beta_{1} \beta_{2} & =\text { Koefisien regresi } \\
\mathrm{X}_{1} & =\text { Manajemen laba } \\
\mathrm{X}_{2} & =\text { Asimetri Informasi } \\
\mathrm{e} & =\text { Kesalahan Residual (error) }
\end{array}
$$




\section{HASIL PENELITIAN DAN PEMBAHASAN}

Tabel 2. Hasil Uji Normalitas

One-Sample Kolmogorov-Smirnov Test

\begin{tabular}{|ll|r|}
\hline & & \multicolumn{1}{|c|}{$\begin{array}{c}\text { Unstandardized } \\
\text { Residual }\end{array}$} \\
\hline N & Mean & 84 \\
Normal Parameters & & .0000000 \\
& Std. Deviation & .91759259 \\
Most Extreme Differences & Absolute & .134 \\
& Positive & .134 \\
& Negative & -.117 \\
Kolmogorov-Smirnov Z & & 1.229 \\
Asymp. Sig. (2-tailed) & & .097 \\
\hline
\end{tabular}

Pengujian terhadap normalitas residual dengan menggunakan uji Kolmogorov-Smirnov, mempunyai nilai Kolmogorov-Smirnov sebesar 1,229 dengan nilai signifikansi sebesar 0,097. Hal ini berarti data residual terdistribusi normal.

\section{Hasil Uji Asumsi Klasik}

Tabel 3. Hasil Uji Multikolinieritas

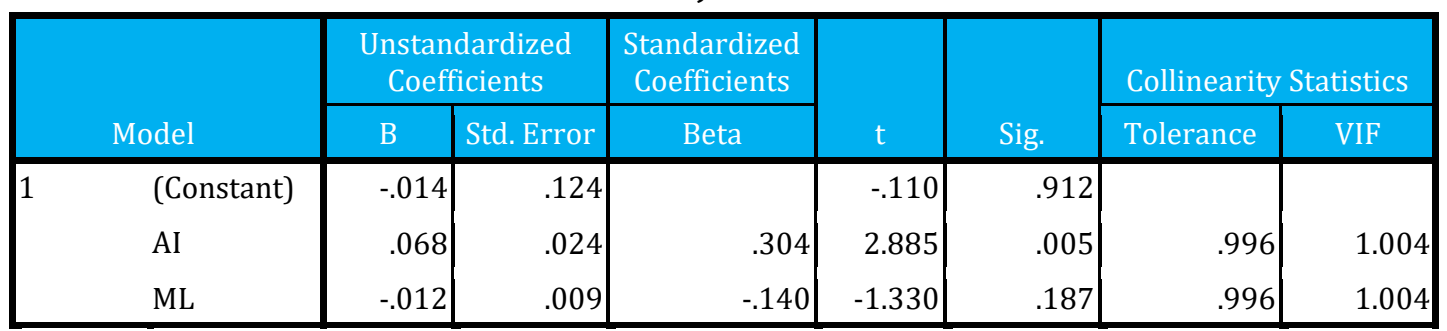

Tabel 4. Hasil Uji Heteroskedastisitas

\begin{tabular}{|c|c|c|c|c|c|c|}
\hline \multirow{2}{*}{\multicolumn{2}{|c|}{ Model }} & \multicolumn{2}{|c|}{ Unstandardized Coefficients } & \multirow{2}{*}{$\begin{array}{c}\begin{array}{c}\text { Standardized } \\
\text { Coefficients }\end{array} \\
\text { Beta }\end{array}$} & \multirow[b]{2}{*}{$\mathrm{t}$} & \multirow[b]{2}{*}{ Sig. } \\
\hline & & B & Std. Error & & & \\
\hline \multirow[t]{3}{*}{1} & (Constant) & .727 & .081 & & 8.969 & .000 \\
\hline & AI & -.011 & .015 & -.081 & -.734 & .465 \\
\hline & ML & .006 & .006 & .121 & 1.096 & .276 \\
\hline
\end{tabular}

Tabel 5. Hasil Uji Autokorelasi

\begin{tabular}{|l|r|r|r|r|r|}
\hline Model & R & R Square & Adjusted R Square & S. E of the Estimate & Durbin-Watson \\
\hline 1 & $.326^{\mathrm{a}}$ & .107 & .085 & .92885181 & 1.824 \\
\hline
\end{tabular}

Berdasarkan hasil perhitungan multikolinieritas, maka diketahui bahwa pada kedua variabel nilai tolerance dan VIF adalah 0,996 dan 1,004. Sehingga semua variabel independen pada model regresi mempunyai nilai tolerance $>0,10$ dan VIF $<10$, dengan demikian dapat disimpulkan bahwa model regresi bebas dari masalah multikolinieritas.

Pada Uji Heteroskedastisitas menunjukkan bahwa signifikansi pada variabel AI (Asimetri Informasi) adalah sebesar 0,465 dan pada variabel ML (Manajemen Laba) sebesar 0,276. Ini menunjukkan signifikansi semua variable > 0,05 sehingga dapat disimpulkan bahwa model regresi tidak terjadi heteroskedastisitas.

Dan pada uji autokorelasi hasilnya menunjukkan nilai Durbin-Watson 1,824. Nilai ini akan dibandingkan dengan nilai signifikansi 0,05 . Untuk jumlah data $n=84$ dan variabel independen swbanyak 2 variabel $(\mathrm{k}=2)$. Berdasarkan tabel durbin-watson, hasil pengujian regresi diatas menunjukkan bahwa 
nilai tersebut terletak diantara du $(1,6942)$ dan dL $(4-1,5969=2,4031)$. Jika dimasukkan dalam kriteria jadi $1,6942<1,824<2,4031$. Maka dapat disimpulkan bahwa tidak terdapat masalah autokorelasi dalam penelitian ini.

\section{Pengujian Hipotesis}

\section{Tabel 6. Hasil Uji t}

Coefficients

\begin{tabular}{|c|c|c|c|c|c|c|}
\hline \multirow{2}{*}{\multicolumn{2}{|c|}{ Model }} & \multicolumn{2}{|c|}{ Unstandardized Coefficients } & \multirow{2}{*}{$\begin{array}{l}\begin{array}{l}\text { Standardized } \\
\text { Coefficients }\end{array} \\
\text { Beta }\end{array}$} & \multirow[b]{2}{*}{ t } & \multirow[b]{2}{*}{ Sig. } \\
\hline & & B & Std. Error & & & \\
\hline \multirow[t]{3}{*}{1} & (Constant) & -.014 & .124 & & -.110 & .912 \\
\hline & AI & .068 & .024 & .304 & 2.885 & .005 \\
\hline & ML & -.012 & .009 & -.140 & -1.330 & .187 \\
\hline
\end{tabular}

Tabel 7. Hasil Uji F

ANOVAa $^{\mathrm{a}}$

\begin{tabular}{|ll|r|r|r|r|r|}
\hline Model & & Sum of Squares & df & Mean Square & F & \multicolumn{1}{c|}{ Sig. } \\
\hline 1 & Regression & 8.339 & 2 & 4.169 & 4.832 & $.010 \mathrm{a}$ \\
& Residual & 69.884 & 81 & .863 & & \\
Total & 78.223 & 83 & & & \\
\hline
\end{tabular}

Tabel 8. Koefisien Determinasi $\left(\mathbf{R}^{2}\right)$

\begin{tabular}{|l|r|r|r|c|}
\hline \multicolumn{1}{|c|}{ Model Summary } \\
\hline Model & \multicolumn{1}{|c|}{$\mathrm{R}$} & \multicolumn{1}{|c|}{ R Square } & Adjusted R Square & $\begin{array}{c}\text { Std. Error of the } \\
\text { Estimate }\end{array}$ \\
\hline 1 & $.326 \mathrm{a}$ & .107 & .085 & .92885181 \\
\hline
\end{tabular}

Pengujian hipotesis dilakukan dengan menggunakan analisis regresi berganda Berdasarkan hasil analisa, diketahui bahwa analisi regresi menghasilkan R square sebesar 0.107. hal ini berarti bahwa biaya modal ekuitas dapat dijelaskan dengan variabel asimetri informasi dan manajemen laba sebesar 10,7\%. Nilai R square dalam penelitian ini masih sangat rendah, dimana semua variabel independen dalam penelitian ini hanya mampu mempengaruhi variabel dependen sebesar 10,7\% sedangkan sisanya 89,3\% dijelaskan oleh variabel lain di luar model penelitian ini. Pada uji Parsial (Uji t) variabel Asimetri Informasi (AI) diperoleh nilai koefisien regresi dengan arah positif sebesar 0,068. Hasil thitung sebesar 2,885 dengan probabilitas sebesar 0,005 yang nilainya dibawah 0,05 . Dengan demikian $\mathrm{H}_{1}$ diterima, yang artinya asimetri informasi berpengaruh positif dan signifikan terhadap biaya modal ekuitas, sedangkan pada variabel manajemen laba menunjukkan bahwa koefisien regresi dengan arah negatif sebesar 0,012. Hasil thitung sebesar -1,330 dengan probabilitas 0,187 yang nilainya lebih besar dari 0.05, sehingga dapat diartikan bahwa manajemen laba (ML) tidak berpengaruh signifikan terhadap biaya modal ekuitas sehingga $\mathrm{H}_{2}$ ditolak. Sedangkan untuk uji simultan (Uji F), di dapat Fhitung sebesar 4,832 dengan probabilitas sebesar 0,010 dan derajat df1 = 2 dan df2 = 81 maka $F_{\text {tabel }}$ yang didapat $(2 ; 81)=3,109$. Dalam

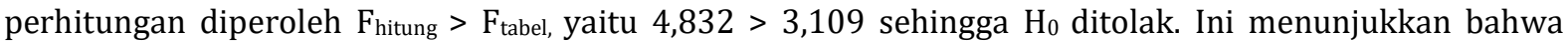
secara simultan terdapat pengaruh antara asimetri informasi dan manajemen laba terhadap biaya modal ekuitas sehingga $\mathrm{H}_{3}$ diterima.

Berpengaruhnya asimetri informasi terhadap biaya modal ekuitas dikarenakan asimetri informasi menyebabkan risiko informasi semakin tinggi. Tingginya risiko informasi akan berdampak pada tingginya biaya ekuitas yang dikeluarkan perusahaan. Penelitian Lang dan Lundlolm (1996) dalam Murni (2003:318) mengemukakan bahwa keuntungan potensial terhadap ungkapan termasuk meningkatnya investor yang mengikutinya, mengurangi estimasi risiko dan mengurangi asimetri informasi yang masing-masing menunjukkan pengurangan biaya modal ekuitas perusahaan.

Penurunan asimetri informasi menyebabkan penurunan biaya transaksi, dimana biaya transaksi diwakili oleh bid ask spread (murwaningsari, 2012). Biaya modal ekuitas digunakan untuk menentukan tingkat pengembalian investasi. Bila investasi meningkat, biaya modal ekuitas akan menurun. Dampak adanya asimetri informasi juga bisa dilihat pada volume perdagangan saham dan spread terjadi. Ketika 
asimetri informasi meningkat, hal itu dapat menyebabkan volume perdagangan kecil karena investor meragukan keakuratan laporan keuangan mereka yang mempengaruhi tingkat pengembalian yang diharapkan oleh investor. Pendapat lain mengenai pentingnya asimetri informasi oleh Purwanto (2013) menjelaskan bahwa ketika asimetri informasi meningkat, keputusan pengungkapan yang dibuat oleh manajer dapat mempengaruhi harga saham karena adanya informasi asimetris antara investor yang lebih banyak informasi dan investor kurang mengetahui biaya transaksi, sehingga mengurangi likuiditas diharapkan di pasar saham perusahaan. Ini berarti semakin kecil asimetri informasi yang terjadi di kalangan pelaku pasar modal akan menjadikan biaya modal ekuitas yang dikeluarkan perusahaan lebih kecil.

Hasil penelitian ini konsisten dengan penelitian Murni (2003) dan Dewi dan Chandra (2016) yang menjelaskan bahwa semakin kecil asimetri informasi maka biaya modal ekuitas juga semakin turun begitu juga sebaliknya jika asimetri informasi semakin tinggi nilainya maka biaya modal ekuitas juga akan semakin naik. Namun berbeda dengan penelitian dari Ifonie (2012) dan Perwira (2015) yang menjelaskan bahwa asimetri informasi tidak berpengaruh signifikan terhadap biaya modal ekuitas.

Sedangkan tidak berpengaruhnya manajemen laba terhadap biaya modal ekuitas disebabkan oleh adanya antisipasi manajemen laba yang dilakukan oleh para investor dan juga mereka tidak hanya melihat dari hasil laporan keuangan khususnya laporan laba rugi tetapi melihat adanya faktor lain dalam mengambil keputusan atas investasinya. Hasil penelitian Leuz et al dalam Utami (2005) menyatakan jika dibandingkan dengan negara ASEAN, Indonesia merupakan negara yang memiliki tingkat overstate earnings dalam manajemen laba paling besar. Hasil penelitian ini tidak konsisten dengan penelitian dari Utami (2005) dan Jumirin (2011) yang menyatakan bahwa manajemen laba berpengaruh psitif dan signifikan terhadap biaya modal ekuitas yang artinya semakin tinggi manajemen laba maka semakin tinggi juga biaya modal ekuitas.

\section{KESIMPULAN}

Asimetri Informasi berpengaruh positif dan signifikan terhadap Biaya Modal Ekuitas perusahaan manufaktur yang terdaftar di Bursa Efek Indonesia periode 2013-2015 yang ditunjukkan dengan nilai koefisien regresi sebesar 0,068 dengan signifikansi 0,005 $(<0,05)$. Selanjutnya, Manajemen Laba tidak berpengaruh signifikan terhadap Biaya Modal Ekuitas. Hasil ini ditunjukkan oleh nilai koefisien regresi sebesar -0,012 dengan signifikansi lebih besar daripada 0,05 yaitu sebesar 0,187.

\section{SARAN}

1. Menambah variabel lain yang dapat mempengaruhi biaya modal ekuitas.

2. Menggunakan periode waktu penelitian yang lebih lama untuk mengetahui kondisi pasar modal yang sesungguhnya.

3. Menggunakan sampel perusahaan dengan nilai buku ekuitas positif dan negatif dan juga perusahaan sektor non manufaktur.

\section{DAFTAR PUSTAKA}

Dewi, S.P. \& J.S. Chandra. 2016. Pengaruh Pengungkapan Sukarela, Asimetri Informasi dan Manajemen Laba Terhadap Cost of Equity Capital pada Perusahaan Manufaktur. Jurnal Bisnis dan Akuntansi, Vol.18, No.1.

Heriyanthi, R. 2013. Pengaruh Pengungkapan Sukarela dan Manajemen Laba Pada Cost Of Equity Capital Dengan Asimetri Informasi Sebagai Variabel Intervening. Jurnal Akuntansi Universitas Udayana. ISSN:2302-8556.

Ifonie, R.R. 2012. Pengaruh Asimetri Informasi Dan Manajemen Laba Terhadap Cost Of Equity Capital Pada Perusahaan Real Estate Yang Terdaftar Di Bursa Efek Indonesia. Jurnal Ilmiah Mahasiswa Akuntansi, Vol 1, No. 1, Januari.

Jumirin. 2011. Pengaruh Manajemen Laba Terhadap Biaya Modal Ekuitas Pada Perusahaan Otomotif Yang Terdaftar Di Bursa Efek Indonesia. Jurnal Riset Akuntansi Dan Bisnis, Sumatera Utara, Vol.11, No.2.

Murni, S.A. 2003. Pengaruh Luas Ungkapan Sukarela dan Asimetri Informasi terhadap Cost of Equity Capital pada Perusahaan Publik di Indonesia. Makalah dipresentasikan dalam Simposium Nasional Akuntansi VI Surabaya, 16 - 17 Oktober.

Murwaningsari, E. 2012. Faktor Faktor Yang Mempengaruhi Cost Of Capital (Pendekatan: Structural Equation Model). Fakultas Ekonomi Universitas Trisakti. 
Nuryaman. 2014. The Influence of Asymmetric Information on the Cost Of Capital with the Earnings Management as Intervening Variable. Journal of Advanced Management Science Vol, 2, No 1, March 2014.

Perwira, A.B. 2015. Analisa Pengaruh Manajemen Laba Dan Asimetri Informasi Terhadap Cost Of Equity Capital. Jurnal Akuntansi Diponegoro, Vol.4, No.4.

Pratista, C.A. 2012. Pengaruh Manajemen Laba Terhadap Biaya Modal Ekuitas Melalui Pengungkapan Corporate Social And Environmental Responsibility Sebagai Variabel Intervening. Jurnal Skripsi Universitas Atma Jaya.

Purwanto, A. 2013. Pengaruh Manajemen Laba, Asymetri Information dan Pengungkapan Sukarela Terhadap Biaya Modal.

Sulistyanto, S. 2014. Manajemen Laba: Teori dan Model Empiris. Jakarta: Grasindo.

Utami, W. 2005. Pengaruh Manajemen Laba Terhadap Biaya Modal Ekuitas (Studi pada Perusahaan Manufaktur). Simposium Nasional Akuntansi VIII, 15 - 16 September: 100-116. 